\title{
A Textual Discourse Analysis of Introductions in Textbooks of Humanities and Basic Sciences
}

\author{
Sara Shahab \\ Islamic Azad University, Shiraz Branch \\ Nasser Rashidi \\ Shiraz University \\ Firooz Sadighi \\ Islamic Azad University, Shiraz Branch \\ Mortaza Yamini \\ Zand Institute of Higher Education, Shiraz
}

\begin{abstract}
This study attempted to scrutinize the disciplinary and cross-disciplinary generic variations of textbook introductions in humanities and basic sciences with reference to the onion model. The data included a sample of 60 introductions (i.e. ten each from applied linguistics, sociology, and psychology within humanities, and ten each from biology, agriculture, and geology within basic sciences). Humphrey and Economou's (2015) onion model of discourse analysis was adopted, and MAXQDA 10 software of qualitative analysis was used for coding. The findings revealed similarities and differences not only within but also between the two disciplines, which can be attributed to the nature of disciplines as well as the generically accepted conventions in each discipline. Moreover, the results of the study highlighted the predominance of descriptive and analytical phases in textbook introductions not only in isolation but also in establishing more complicated genres like persuasion and critique. The study highlights the importance of teaching which is concerned with learners' rhetorical consciousness-raising of the disciplines as well as the discipline-specific lexicogrammatical features in expert texts.
\end{abstract}

\section{Résumé}

Cette étude visait à examiner attentivement les variations génériques disciplinaires et interdisciplinaires des introductions de manuels dans les sciences humaines et les sciences fondamentales en se référant au modèle de l'oignon. Les données comprenaient un échantillon de 60 introductions, c'est-à-dire dix introductions dans chacune des disciplines des sciences humaines (la linguistique appliquée, la sociologie et la psychologie) et dix autres pour chacune des disciplines des sciences fondamentales (biologie, agriculture et géologie). Le modèle de l'oignon d'Humphrey et Economou (2015) pour l'analyse du discours a été adopté et le logiciel d'analyse qualitative MAXQDA 10 a été utilisé pour le codage. Les résultats ont révélé des similitudes et des différences non seulement au sein des deux disciplines, mais aussi entre elles, ce qui peut être attribué à la nature des disciplines ainsi qu'aux conventions généralement acceptées dans chaque discipline. De plus, les résultats de 
l'étude ont souligné la prédominance des étapes descriptives et analytiques dans les introductions de manuels, non seulement isolément, mais aussi dans la création des genres plus compliqués comme la persuasion et la critique. L'étude souligne l'importance de l'enseignement qui se soucie de la prise de conscience rhétorique des apprenants de ces disciplines ainsi que des caractéristiques lexico-grammaticales spécifiques à la discipline dans les textes spécialisés.

\section{A Textual Discourse Analysis of Introductions in Textbooks of Humanities and Basic Sciences}

In recent decades, an investigation of discourse patterns and schematic structure of textbooks across disciplines, particularly their introductions, has been a significant and exciting research area due to the priority given to scaffolding students to make meanings with these texts. However, previous studies have been relatively limited in their scope, as they focused on a few specific genres, and there seems to be room for studies that take into account other disciplines.

It is now well established that academic textbooks are an important genre in academic settings. Hyland (2000) contended that "university textbooks are something of a neglected genre; little is known about their rhetorical structure and their relationship to other genres" (p. 14). Nevertheless, there are relatively few studies in the area of textbook introductions, most of which are narrow in focus dealing only with genre analysis concerning Swales' (1990) Creating a Research Space (CARS) model and Bhatia's (1993) model of genre analysis.

Regarding disciplinary studies on textbooks, Bhatia (1997) studied the introductory genres of academic textbooks and their various realizations. Swales' (1990) CARS model and Bhatia's (1993) model of genre analysis were used to investigate the functional and the structural conventions of the introductory genres of the academic textbooks. Moreover, Bhatia's (1997) study considered the influence of promotions in the construction of generic conventions which led to the mixture of genre values from a utilitarian view of genre construction, interpretation, and use.

In much the same vein, Jalilifar and Golkar Musavi (2016) utilized Swales's (1990) views of a genre to investigate genre-mixing in the rhetorical structures of 75 prefaces, introductions, and forewords in applied linguistics textbooks. The findings revealed the same generic conventions across prefaces, introductions, and forewords. Furthermore, the analysis highlighted the way in which the writers used generic conventions with the purpose of informing and promoting.

It appears that most of the disciplinary studies on textbooks highlighted the need to focus more on identifying the structure of textbook introductions, which are of considerable importance to students since they play an essential role in familiarizing the students with their disciplines, thus influencing their first impressions of their disciplines. Concerning cross-disciplinary studies, Hyland (1999) examined extracts from 21 introductory textbooks across disciplines of microbiology, marketing, and applied linguistics, and subsequently compared them with 21 research articles from the disciplines mentioned above. He maintained that the analysis of metadiscourse in specific disciplines and genres shows how intrinsically metadiscourse relates to its rhetorical context. Nevertheless, despite being an interdisciplinary study, his focus was primarily on the 
analysis of metadiscourse markers, with little attention paid to the schematic and discourse structures in these disciplines.

In a similar vein, to reveal the linguistic challenges of different genres and disciplines, Schleppegrell (2004) focused on the register features of the texts in schooling and concluded that the "language of schooling" is a register that offers students a way to authoritatively demonstrate knowledge in texts that have certain rhetorical structuring. Analysis of the genres involved in master's theses in the US was first carried out by Samraj (2008). Focusing on the introductions, she investigated the overall organization and discourse of master's theses across three disciplines: biology, philosophy, and linguistics. The results showed that authors in philosophy used citations and the first person pronoun in the introductory sections in order to express their authority. However, authors in philosophy established fewer references to previous research than the authors in biology. Finally, the authors in linguistics occupied a more central position concerning these dimensions.

In another study, Abdollahzadeh \& Salarvand (2013) provided an in-depth analysis of generic structure, linguistic features, and potential disciplinary differences of academic book prefaces in the three disciplines of management, metallurgy, and mathematics. Their study indicated that book prefaces in the afore-mentioned areas are similar to each other concerning communicative intentions, schematic structure, and readers 'views.

Parodi (2014) studied 126 university textbooks across four disciplines, namely, basic sciences, engineering, social sciences, and humanities. Additionally, specific disciplines, such as social work, psychology, industrial chemistry, and construction engineering, were examined. The study was done to identify macro-moves, moves, and steps across disciplines. The results highlighted differences in some moves and steps across disciplines and revealed a significant feature in the teaching content of textbooks.

Furthermore, the study did not point to any remarkable difference in the employment of the moves and steps in the book prefaces in the three disciplines. Last but not least, the findings revealed that book prefaces both promote and inform the readers.

Atai and Asghari (2017) investigated the employment of interactional metadiscourse devices in a corpus of 200 English academic online blurbs taken from 16 topranking university press websites. The findings revealed that disciplinary fields account for significant variations concerning the frequency of moves and interactional meta-discourse markers. Three obligatory rhetorical moves and four optional moves were also identified.

The importance of investigating the genre of academic textbooks has been stressed in a variety of studies (Hyland, 2000; Swales, 1995). Many of these studies have focused on the discourse patterns in textbook introductions. Yet to the best of the researchers' knowledge, none of them have examined textbook introductions with reference to Humphrey and Economou's (2015) onion model of discourse analysis, except for Humphrey and Economou (2015) themselves who explore description, analysis, persuasion, and critique as four discourse patterns in academic writing. Thus, the present study aims to analyze patterns of language used in the introductory sections of sixty textbooks in the disciplines of humanities and basic sciences using the onion model of critical discourse analysis, to identify disciplinary and cross-disciplinary variations. 


\section{Research questions}

The study aimed to answer these research questions:

1. What can the onion model reveal about textbook introductions both across and within disciplinary areas?

2. What are the similarities and differences in introductions both across and within disciplinary areas?

\section{Materials}

\section{Method}

The data included the introductions of 60 introductory textbooks available online, i.e., 10 introductions, from each discipline of applied linguistics, sociology, psychology, biology, agriculture, and geology. Furthermore, all of the introductory textbooks were in English and written by native speakers. The length of the texts ranged from 591 to 5796 words with a mean of 3193.5 words and a standard deviation of 3680.491 . The textbooks were published from 1966 until 2018. Hard and soft disciplines were selected to be compared.

The introductions to first-year textbooks were selected due to them being the first books introducing the students to the discipline and hence playing a key role in familiarizing and acculturating them into their disciplines. According to Bhatia (2004):

Textbooks [...] disseminate discipline-based knowledge and, at the same time, display a somewhat unequal writer-reader relationship, with the writer as the specialist and the reader as the non-initiated apprentice in the discipline, or the writer as the transmitter and the reader as the recipient of established knowledge ( $\mathrm{p}$. $33)$.

Bhatia (1998) suggested that the purpose of the academic textbook is to "make accessible established knowledge in a particular discipline to those readers who are being initiated into a specific disciplinary culture" (p. 17).

\section{Procedures}

Data collection. The introductions of the textbooks were extracted by the researchers. Next, specific conventional (lexico-grammatical) features within the texts, which reflected the four patterns of the onion model (i.e., description, analysis, persuasion, and critique), were identified and coded using MAXQDA 10 software with reference to the onion model of analysis (Humphrey \& Economou, 2015).

Regarding "description" in the Onion model, Martin and Rose (2008) held that "in educational contexts at the school level, 'description' has been identified as a fundamental genre in literary and factual apprenticing texts, distinguished by the absence of unfolding sequences of events and by a focus on specific entities" (p. 5). Moreover, Woodward-Kron (2005) asserted that the inclusion of descriptive genres, like examples, allowed the students 
to develop and expand knowledge in expository writing. This descriptive genre focuses on presenting information and facts.

The descriptive patterns were classified into entity-based descriptive and eventfocused descriptive categories. Entity-based descriptive phases focus on describing objects and entities, however, event-focused phases represent a recount or recall of a series of events. The pattern of analysis reflects the relationships between different phases of the texts. "Analysis" refers to the logical organization of information in expository writing. In other words, Humphrey and Economou (2015) pointed out that analysis deals with reorganizing information, comparing and contrasting, finding relationships, types, and parts in the onion model of analysis.

What's more, "critical analysis" integrates analysis with critique in broader linguistic theories and some academic writing tasks. (Ballard \& Clanchy, 1984; Cottrell, 2008; Humphrey \& Economou, 2015). Coffin and Donohue (2012) held that critical analysis "moves beyond description and explanation to a critical position, asking questions about how different practices constrain as well as enable meaning making" (p. 67).

Concerning analysis, Humphrey and Economou (2015) mentioned that it is not considered a genre in systemic functional linguistics (SFL). Rather, It has been used to specify a type of exposition used in academic discourse, i.e. "analytical exposition" (Humphrey, 1996; Martin \& Peters, 1985) and a type of longer article in the media context, i.e. "news analysis" (Iedema, White, \& Feez, 1994; Martin \& White, 2005). Analysis in both genres refers to the taxonomic and logical organization of information whether in the service of argument in exposition or the expository news report (p. 39).

Moreover, "persuasion" is concerned with putting the arguments forward and providing reasons to justify them. Humphrey and Economou (2015) maintained that "in the teaching work of the Learning Centre, however, persuasion (arguing for the writer's position) is distinguished from critique (challenging external positions)" (p. 39). They also contended that persuasion typically involves a claim, followed by some grounds which both positions the reader to accept that proposition and to establish the background for the second claim.

To put it in other words, persuasion is concerned with taking a stance or position, making a claim, and then interpreting or developing an argument. Persuasive language, as mentioned by Humphery and Economou (2015), is discipline-specific and value-laden. Table 1 shows the classification of the four discourse patterns applied in the study.

Table 1 Classification of the four discourse types with reference to the onion model

Discourse Patterns

Entity-based description

Event-focused description

Analysis

Persuasion

Critique 


\section{Data analysis}

\section{Analytic framework of the study}

The study was based on the onion model of discourse analysis developed by Humphrey and Economou (2015). The framework rests on the relationship between the four discourse patterns in academic writing: description, analysis, persuasion, and critique. The analysis also employed SFL with reference to genre and register theory (Martin, 1992; Martin \& Rose, 2008). SFL helped us deconstruct texts according to their schematic features.

Thompson (2004) states that SFL describes "language in use" rather than language as a "set of generalized rules detached from any particular context of use" (p. 1). Language and context are interconnected based on SFL theory. The SFL approach to genre builds upon register theory, which deals with the variables of the context: field (the content of the text), tenor (social activity), and mode (method of communication). According to Martin (1998), genres are "staged, goal-oriented social processes" (p. 412), realized through the three constituents of register: field, tenor, and mode.

Registers have been typically analyzed regarding three variables mentioned previously: field, tenor, and mode, which relate to the kind of activity which discourse employs to present the ideas, the status, the role of participants, and the channel of communication, respectively. Martin (1985) makes a three-way distinction between genre, register, and language. He believes that genres are realized via registers, and then registers are realized via language. Furthermore, field, tenor, and mode are associated with experiential, interpersonal, and textual meta-functions respectively. The ideational metafunction is about the way in which human experience is constructed. According to Halliday and Matthiessen (2004), Contrary to the ideational metafunction, the interpersonal metafunction represents "language as action" (p. 30), and how human relationships are established. In written language, interpersonal meanings are defined in terms of the relationship between writer and reader. While the ideational and interpersonal metafunctions are both "extra-linguistic phenomena dealing with the social and the natural world" (Matthiessen \& Halliday, 1997, as cited in Fryer, 2007), the textual metafunction is related to the realization of ideational and interpersonal meanings. It presents human experience and human relationships in terms of text (written or spoken) in a particular context. Figure 1 shows that meaning in texts is determined by (1) context of culture, (2) context of situation, and (3) metafunctions. 


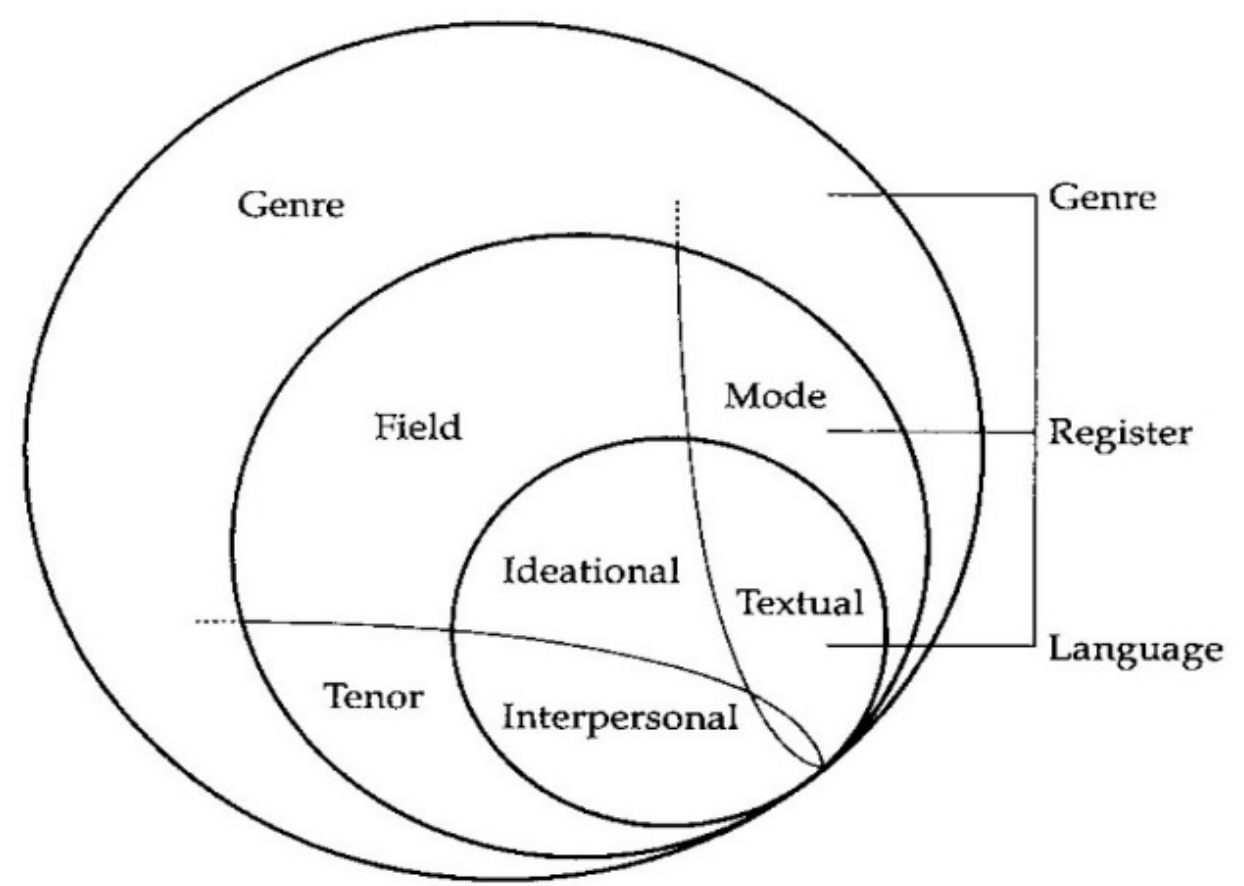

Figure 1. Metafunctions in relation to register and genre in semiotics (adapted from Martin, 2001a, p. 46).

\section{Procedure}

The analysis was carried out based on Humphrey and Economou's (2015) onion model. This model mainly draws on developments in systemic functional linguistics. According to Humphrey and Economou (2015), "the term onion is symbolic of the relationship between four different types of discourse patterns or functions of writing found to be highly valued across academic disciplines" (p. 40). Figure 2 shows this relationship between the onion's layers, which is one of dependency. 


\section{The Onion}

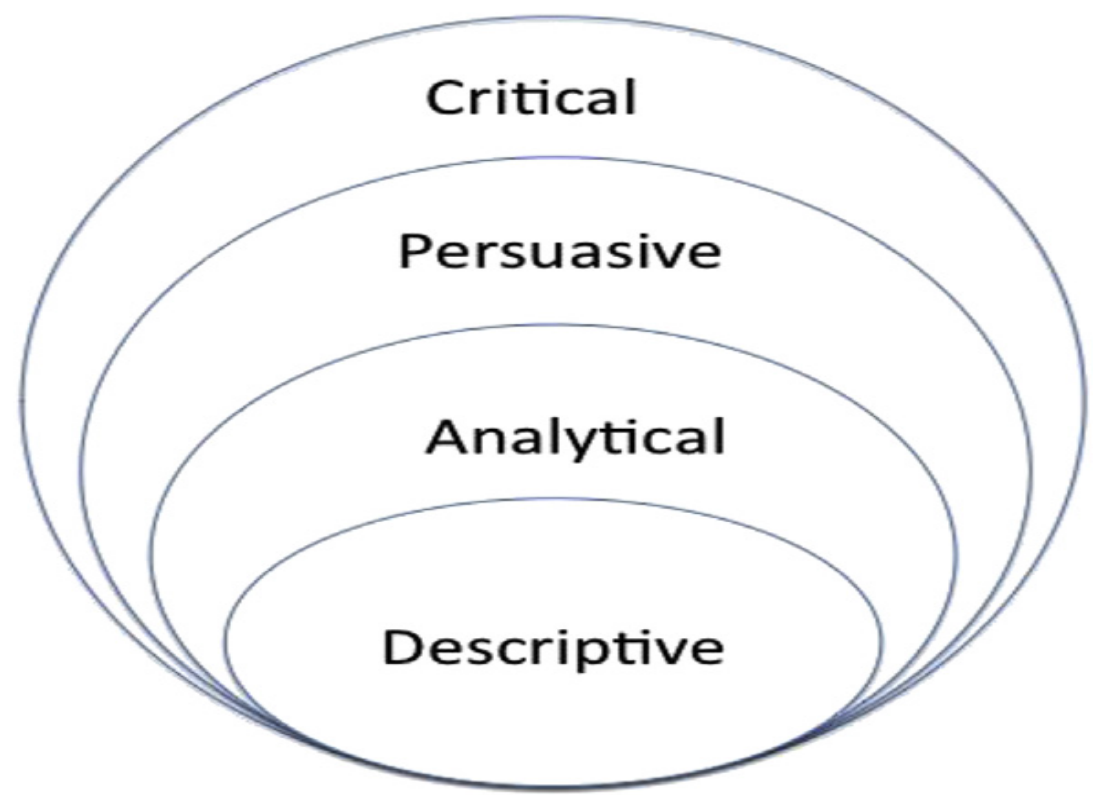

Figure 2. The onion model of critical analysis (adapted from Humphrey \& Economou, 2015, p. 41).

As far as the description layer was concerned, it aimed to provide facts or information. Humphrey and Economou (2015) indicated that the onion model considers two ways of achieving description in academic writing. The traditional description is accomplished via focusing on entities (i.e., people, things, and qualities typically represented within noun groups). Furthermore, the conventional description was concerned with two ways of presenting entities. Entity-based descriptions were created by focusing on "the way things are." As Humphrey and Economou (2105) stated, the entity-based description may include "a list of facts, characteristics or features of a phenomenon, but sometimes including agreed-on taxonomies in a discipline" (p. 41). Humphrey and Economou (2015) also mentioned that the other way of presenting knowledge within the traditional description approach is event-focused, "telling what happened by recounting a series of events or activities (here subsumed within the term description)" (p. 41).

Concerning the second layer of the onion, namely, analysis, it consisted of descriptive writing (i.e., facts or information), with the added feature of reorganization of information. Consequently, in an analytical genre, the author not only gave information but also reorganized it into categories, groups, parts, types, or relationships. Humphrey and Economou (2015) argued that analysis is distinguished from description in the onion model in that, "in analysis, information is not presented as the way things are in the field, but as the way the writer chooses to represent information in the field in order to address the concerns of their text" (p. 42).

As a result, Humphrey and Economou (2015) held that analytical writing refers to the reorganization of information in the field in some original way for the text. So, information was not presented mainly as a list of facts or taxonomies. Instead, it was organized either regarding original taxonomies (via classification, elaboration, or composition), or logical relations (by addition, comparison and contrast, conclusion). 
Considering the third layer of the onion (i.e. persuasion) Humphrey and Economou (2015) highlighted that this academic genre "argues for an explicit evaluation of, or claim about either ideas in the field, which Hood (2010) refers to as the 'object of study' and/or of ideas of specified scholars (i.e. the 'field of study')" (p. 44). In other words, it includes facts, reorganization of information, and the added feature of the writer's point of view.

At the tertiary level, persuasion is typically realized through analytical exposition, which, according to Coffin (2006), consists of three stages to "put forward a point of view: thesis (background), thesis arguments; and reinforcement of thesis" (p. 45). Martin and Rose (2008) indicated that "at the more delicate level of phase structure, persuasive discourse patterns typically unfold with a "claim" phase, which provides the position of the writer followed by a "grounds" phase which provides reasoning to justify this claim" ( $p$. 13). As Humphrey and Economou (2015) stated, "the two steps are always linked to causal relations, which may be expressed implicitly or explicitly through different linguistic forms" (p. 45).

What's more, the interaction of evaluative choices from the different systems of appraisal is crucial in achieving the persuasive function. According to Lee (2009), appraisal theory has been developed within the broader theoretical framework of systemic functional linguistics (SFL) and focused on the interpersonal meta-function of language. Hence, systems of attitude, engagement, and graduation and their sub-systems (affect, appreciation, judgment; monogloss, heterogloss; force, focus) were considered to be important in persuasive writing.

White (2015) held that attitude is concerned with "meanings by which texts convey positive or negative assessments", graduation is related to "the intensity or directness of such attitudinal utterances which are strengthened or weakened", and Engagement deals with assertions "by which speakers/writers engage dialogically with prior speakers or with potential respondents to the current proposition" (p. 1). Figure 3 shows the main categories and sub-categories of the appraisal system.

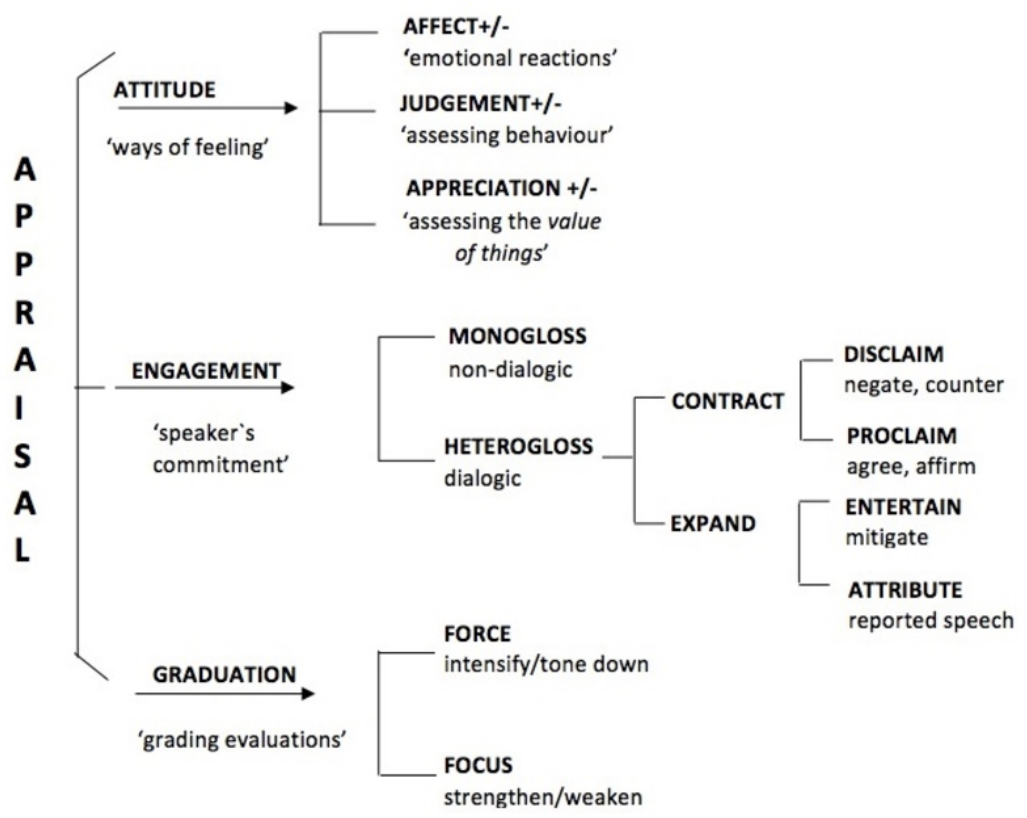

Figure 3. Appraisal Framework (adapted from Martin and White, 2005, p. 38). 
As shown in Figure 3, the appraisal system involves three primary systems: attitude, engagement, and graduation. The sub-systems of attitude are appreciation, affect, and judgment. Furthermore, the sub-systems of graduation involve force and focus. Finally, the sub-categories of engagement consist of monogloss and heterogloss. Humphrey and Economou (2015) also suggested that "attitude and dialogic positioning achieved via engagement choices contributes significantly to persuasion" (p. 6). White (2015) argued that the appraisal literature divides attitudinal meanings into the following three broad subtypes: (1) positive/negative assessment presented as emotional reactions (labeled "affect"); (2) positive/negative assessments of human behavior and character by reference to ethics/morality and other systems of conventionalized or institutionalized norms (labeled "judgment"); (3) assessments of objects, artifacts, texts, states of affairs, and processes in terms of how they are assigned value socially (labeled "appreciation"), that is, in terms of their aesthetic qualities, their potential for harm or benefit, their social salience, etc. (p. 2).

Within graduation systems, force refers to utterances which result in strengthening or mitigating propositions, while focus refers to the statements which can result in blurring or sharpening semantic categories. Finally, White (2015) suggested that "one key consequence of this perspective is that all utterances are seen as involving stance-taking on the part of the speaker/writer and hence as involving some form of dialogistic engagement" (p. 6).

Furthermore, whereas the attribution in descriptive and analytical phases was employed to summarize the doings or to report the sayings of researchers, the attribution choices in persuasive discourse were foregrounded to give greater authority to the claim. Additionally, Humphrey and Economou (2015) held that "dialogic choices from the engagement system also interact with choices from attitude and graduation systems to persuade the reader of the claim" (p. 46).

Concerning the last constituent of the onion model (critique), it involved facts, a reorganization of information, the writer's point of view, and above all the feature of including another point of view. To put it another way, critical genre required the author to take into account at least two points of view, including the writer's viewpoint, as opposed to a persuasive genre that only demanded the writer's point of view. Humphrey and Economou (2015) pointed out that critical writing typically challenges "a theoretical notion or aspect of research in an external source, and persuades the reader to accept an authorial alternative/counter position" (p. 46).

Researchers investigating the appraisal system highlighted that an evaluative stance is achieved through the interaction of both ideational and interpersonal and textual meanings (Hood 2004, 2010; Hao and Humphrey 2012). Additionally, the evaluative stance is developed through the interaction of various resources that bring and evaluate external academic sources. Humphrey \& Hao (2012) glossed these configurations of linguistic resources as "burnishing" and "tarnishing." Martin \& White (2005) posited that:

While the starting point for identifying resources for burnishing and tarnishing is ideational meanings, typically the semiotic entities which construe internal or external sources, the primary interpersonal meaning associated with heteroglossic discourse is the Engagement system of Appraisal (p. 97). 
Moreover, Humphrey and Economou (2015) also asserted that critical positioning was used in the introductory sections of dissertations and research articles to establish a gap for the study. The critical writing was also accomplished via "interactions of choices from appraisal systems with ideational choices, in particular, semiotic entities such as internal (authorial) and external sources (e.g., study; 'author (date)'; argument, this essay, I)" (p. 47). Figure 4 represents an annotated onion model, adopted from Humphrey and Economou (2015).

\section{The Onion}

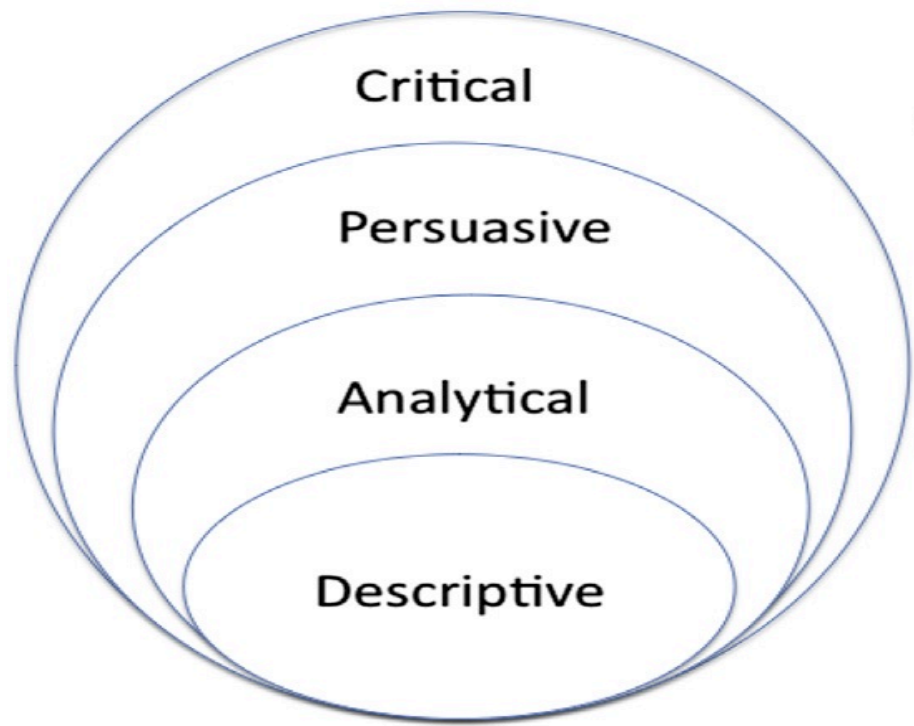

Evaluating
external voices, positions

Taking a position, supporting that position

Re-organising information: finding patterns, categories, relationships

Providing/reproducing information

Figure 4. Annotated onion model (adapted form Humphrey and Economou, 2015).

Firstly, the introductions of applied linguistics, sociology, and psychology textbooks were studied. Then, in order to establish the degree of sub-disciplinary variation in humanities, these three sub-disciplines of humanities were compared. Next, biology, agriculture, and geology textbook introductions were examined. Moreover, they were compared to determine the amount of sub-disciplinary variation in basic sciences. Next, a comparison was made between the two disciplines of basic sciences and humanities to identify disciplinary variations. Lastly, MAXQDA 10 software was used to assign codes and determine the frequency of them in the six sub-disciplines of the humanities and basic sciences. MAXQDA 10 software was chosen because the data was qualitative and noncategorical.

In order to ensure reliability and consistency of coding, another rater independently coded the same 60 textbook introductions with reference to agreed-upon codes. Then, the two coded documents were merged into one in MAXQDA 10. Next, the inter-rater reliability for the two identical documents was assessed by means of MAXQDA 10 . The degree of correlation was $83 \%$, which shows a high level of reliability for the sample.

\section{Results and discussion}

\section{Results and discussion of the qualitative analysis of the data}


The results indicated that the introduction of all textbooks in humanities and basic sciences began with an entity-based descriptive phase, which aimed to establish the background for the study and engage the readers with the topic under investigation. Hence, the aim of the background section was to provide relevant facts and details about the topic of the study and link them to the research questions. Additionally, the textbook introductions were analyzed regarding nominalizations. In all the textbooks, the entitybased descriptive phase involved a variety of nominalizations or abstractions irrespective of disciplines which aimed to provide the background context for the study. This is consistent with Jalilifar, Alipour, and Parsa (2014) who found no significant difference in the use of nominalization in applied linguistics and biology. That is, their study revealed that there was no significant difference in the employment of nominalizations in humanities and basic sciences.

(1) ......an equally comprehensive definition of language..... (Wardhaugh, 2006)

(2) ....the fundamental tenets of learning theory.... (Hilgard et al., 2009)

(3) .......another significant milestone of microscopy.... (Böhmer et al., 2010)

(4) ......the most important contributor to the national income....(Grigg, 2003)

Examples 1 through 4 indicate instances of nominalizations in both disciplines. Furthermore, the engagement choice of graduation was used in the entity-based descriptive phases of the textbooks regardless of discipline. It appeared that the choice of graduation allowed the writer to emphasize the importance of the point he was describing and thereby foreground the background context. Graduation was employed in this stage since the aim of the writers was not to convince the readers of a particular claim, rather, they attempted to show their commitments to previous studies and ideas, thus establishing the significance of the study.

Moreover, more choices of force, and intensification were used in the discipline of humanities. The frequent employment of the choice of graduation might indicate that the writers attempted to go beyond the limits of a descriptive event to state their personal feelings and evaluations. The findings matched those of Draverson and Tagg (2015), who stressed that "the authors' linguistic choices in addition to the frequency of making such choices help to establish relationships with the readers" (p. 11).

(5) I was somewhat surprised....(Hammond, 2010)

(6) Sociology is a relatively new discipline... (Hammond, 2010)

(7) .... but who were also very patient... (Bartels, 2005)

Examples 5, 6, and 7 reveal instances of intensification in humanities. On the other hand, more instances of graduation were found in basic sciences (examples 8, 9, and 10). These results might be due to the fact that in basic sciences the authors aim to present objective facts and data, rather than expressing their feelings.

(8) The more experience you have of this approach... (King, 2010)

(9) ...the vast expanse (King, 2010)

(10) ...many important biological principles...(Belk \& Maier, 2013) 
In the descriptive segments of the textbooks in the discipline of humanities, some questions were found which attempted to challenge and engage the students in the interpretation of problems (examples $11 \& 12$ ). These questions, moreover, indicated the authors' own evaluations and personal inclinations toward the presented theories. The results agree with the ideas of Hyland (2008), who pointed out that effective communication in the soft fields relies more on the author's ability to invoke a true writer in the text.

(11) In this way, the two traditions have come to resemble one another. Or have they? We discuss below whether there is still a distinction. (Davies \& Elder, 2004) (12) The philosopher, of course, will raise questions about the ultimate status of both this "reality" and this "knowledge". What is real? How is one to know? (Berger \& Luckmann, 1966)

In addition, with regard to event-focused descriptive phases, more recount phases were identified in the discipline of sociology with reference to the onion model. So, the results were in accord with the quantitative analysis of the data which also highlighted that more event-focused phases could be found in sociology, and might be justifiable due to the interdisciplinary nature of sociology. In other words, it is essential in sociology to draw on other disciplines so as to investigate major recent social problems (Burawoy, 2013).

Furthermore, the event-focused phase in textbooks primarily represented monoglossic rather than heteroglossic propositions regardless of disciplines (examples 13 and 14). Monogloss or non-dialogic propositions shut down all the negotiations from other voices. The employment of monogloss might suggest that the writers in this event-focused stage attempted to review the events before the present study as well as to outline the objectives of the study. Hence, they didn't want to draw upon other voices to persuade the readers about their ideas. Here, monogloss appropriately fulfilled the rhetorical purposes of the textbook introductions. That is, the maximum authorial investment could be found in this part. The results corroborated the findings of Wang and An (2013) who found more monogloss in overview sections of academic book reviews.

(13) An important resource is the amount of labor that is available within a society. (Debertin, 2012)

(14) ...there is no such "non-evolutionary psychology" in the sense that no other causal processes, other than evolutionary ones, are responsible...(Buss, 2005)

The descriptive phase was followed by an analytic one, which reflected the relationships between different phases of the texts. The findings are consistent with previous studies which concluded that academic writing includes analysis (Humphrey, 2012; Lemke, 1990; Schleppegrell, 2004).

(15) Most modern families fall into one of two types: nuclear, or blended. (Hammond, 2010)

(16) Some specialists mean Language Pedagogy by Applied Linguistics, while others integrate all new linguistic disciplines....(Sarosdy, et al., 2006) 
While example 15 shows types or categories, example 16 is concerned with a contrastive relationship. The analytic phase was followed by a persuasive one. This phase in the textbooks included a thesis, some background information, and a second claim. Therefore, the results were in accord with the onion model of analysis and indicated the need for the students to recognize the three stages in which persuasive phases reveal themselves in their disciplines in order to be professionally accepted within their disciplinary communities.

Furthermore, the results indicated the presence of implicit attitude values in persuasive phases of the discipline of humanities (examples 17 and 18). The results might suggest that the authors in the discipline of humanities attempted to present a highly authorial, personalized subjective voice, which also gave a more personalized tone to their writing, and thereby engaged the readers in the interpretation process. This highly authorial subjective voice was manifested through foregrounding and backgrounding certain kinds of information. Hence, the structure of this persuasive part in humanities was constructed in such a way that knowledge came from the personal involvement of both the writer and the readers.

(17) ....this time-honored intellectual territory is likely to raise the eyebrows of the man in the street and even more likely to enrage the philosopher. (Berger \& Luckmann, 1966)

(18) ... looks as if it ought to fall in the domain of the cognitive psychologist (Radford, et al., 2009)

On the other hand, more explicit attitude values were used in the persuasive phase of basic sciences to present impersonalized, objectified data to the readers. One reason for this is that persuasion in hard disciplines is established by suppressing or downplaying the role of the authors in knowledge-making and giving prominence to the scientific procedure. The findings matched those of Hyland (2005) who held that by reducing human judgment in the interpretation of data and removing the agent, author intervention and personal interests are also reduced.

(19) This revised and updated edition is a much-expanded look at the popular science of paleontology and mineralogy. Readers will enjoy this clear and easily readable text, which is well illustrated with dramatic photographs, clearly drawn illustrations, and helpful tables. The comprehensive Glossary is provided... (Erickson et al., 2014)

Example 19 highlights explicit values, showing a positive assessment of the textbook in the introduction. Moreover, the choice of judgment was used more in humanities to allow the authors to evaluate human behaviors. The results were in agreement with the ideas of Hyland (2005) who maintained that in softer fields of human and social inquiry, such as sociology and linguistics, the representation of reality was always established via the writer's selection and foregrounding of information, and that persuasion requires high author visibility. Some instances of judgment in humanities are provided in examples 21 and 22. 
(20) In doing so, you were acting like a behavioral scientist, a detective of sorts (Contino, 2013)

(21) Also problematic is the somewhat circular nature of this theory; repetitive behavior patterns are assumed to have a function, yet we profess to know that they have a function only because they are repeated. (Griffiths et al., 2017)

In example 21, the author made an analogy between readers and behavioral scientists and detectives. But, in example 21, the author criticizes and challenges the circular nature of the theory, which is not in accord with what the author professes. Furthermore, the choice of appreciation was employed more in the persuasive phase of basic sciences. Appreciation helped the authors evaluate things and entities since it made it possible to shift from a personal attribute to an impersonalized one. (Martin, 2000). Therefore, the use of attitude as appreciation could reduce subjectivity in a text. A possible explanation for this might be the fact that in basic sciences, the writers were not concerned with evaluating human behaviors, rather, they aimed at evaluating scientific events, and sometimes provide the readers with their own claims. Examples 22 and 23 present instances of appreciation in basic sciences.

(22) .... herbs, and other high-value, often perishable, specialty crops. (Pittenger, 2002)

(23) Generally similar plants or animals.... (Muttaqui, et al., 2009)

Additionally, more heteroglossic propositions including footnotes and citations were found in persuasive phases of basic sciences (examples 24 and 25). It seems that scientists have to draw on previous studies due to the linear nature of basic sciences (Hyland, 2003). The findings were in line with studies that highlighted the importance of heteroglossic propositions in establishing persuasive phases in science. (Gallardo, 2005; Parkinson \& Adendorff, 2004; Russell, 2010; Swales, 1990). That is, these studies revealed that science involves a multiplicity of voices that help the authors convince the readers of their claims.

(24) The United States Department of Agriculture (USDA) reported over 2.4 million farms in the United States in 1980... (Debertin, 2012)

(25) ... heed the words of Cornell biologist James G. Needham (1888-1957), who once wrote: It is a monstrous abuse of the science of biology to teach it only in the laboratory... (Rittner \& McCabe, 2004)

Besides, heteroglossic propositions accompanied the choice of entertain and attribute in the persuasive phases of the basic sciences. These two options helped the writers achieve dialogic expansion and take alternative points of view into account.

(26) Geologic formations can be found in most parts of the United States... amateur geologists and collectors will have a better understanding of the forces of nature...

(Erickson et al., 2014)

(27) According to the United Nations (Erickson et al., 2014) 
In example 26, the writer frequently exploits the choice of entertain in locutions such as "Geologic formations can be found", "amateur geologists and collectors will have a better understanding of the forces of nature" by means of epistemic modality (i.e. can, and will). Furthermore, example 27 shows that the author attributes the proposition to another voice in order to provide grounds for his claim. In brief, raising the students' awareness of disciplinary similarities as well as cross-disciplinary differences, and particularly, the importance of deploying the appraisal resources to achieve persuasion should be taken into consideration by the teachers.

The persuasive phase was followed by a critical one, which started with criticizing a theory in another source and persuading the reader to acknowledge the author's counter idea. Persuasion was involved in a critical phase, and the writer's argument was established in terms of analytic and descriptive phases. Hence, the complete structure of the onion model was identified in the critical stage.

(28) Although microeconomics and macroeconomics are often considered to be separate branches of economics (expansion), they are really very closely intertwined (contraction). (Debertin, 2012)

(29) Agriculture is by far the most important of the world's economic activities (expansion)... Yet the study of agriculture receives relatively little attention from geographers (contraction). (Grigg, 2003)

Examples 28 \& 29 show dialogic expansion and contraction in critical phases of the textbook introductions, where a point in literature was first elaborated upon and then narrowed down with concessive conjunction. Additionally, dialogic expansion encompassed the choices of attributing and entertaining, both of which evoked dialogic alternatives. Graduation (i.e. force or intensification) was also employed in critical phases of the articles (e.g. relatively little).

\section{Results and discussion of the quantitative analysis of the data}

Table 2 presents the frequency and percentage of the discourse patterns present in Humanities and Science textbook introductions.

Table 2

The frequency and percentage of the discourse patterns in humanities and basic sciences textbook introductions

\begin{tabular}{lcccccc}
\hline & Humanities & \multicolumn{3}{c}{ Basic sciences } & \multicolumn{3}{c}{$\begin{array}{l}\text { Humanities and Basic } \\
\text { Sciences }\end{array}$} \\
\hline Codes & Frequency & Percentage & Frequency & Percentage & Frequency & percentage \\
\hline $\begin{array}{l}\text { Entity- } \\
\text { based }\end{array}$ & 74 & 16 & 84 & 23.9 & 158 & 21 \\
\hline $\begin{array}{l}\text { Event- } \\
\text { focused }\end{array}$ & 88 & 19 & 74 & 21.1 & 162 & 21.5 \\
\hline Analysis & 103 & 22.3 & 70 & 19.9 & 173 & 23 \\
\hline Persuasion & 58 & 12.6 & 94 & 26.8 & 152 & 20.2 \\
\hline
\end{tabular}




\begin{tabular}{lcccccc}
\hline Critique & 54 & 11.7 & 29 & 8.3 & 83 & 10.9 \\
\hline Total & 377 & 100 & 351 & 100 & 753 & 100 \\
\hline
\end{tabular}

Furthermore, Table 2 shows that more entity-based descriptive phases could be seen in basic sciences. It appeared that in humanities, the authors included more of theoretical concepts and ideas, whereas the authors in basic sciences included more scientific definitions and descriptions. To put it simply, in humanities research is less linear; the literature covers a broad area of research; the issues are more controversial; and the readers are more heterogeneous (Hyland, 2015). Thus, a shared schema could not be assumed for the readers in humanities. Rather, the authors establish a context by providing a great deal of concrete and abstract entity-based descriptive phases. On the other hand, more entitybased descriptive phases were identified in basic sciences. The results may be related to the fact that in basic sciences the authors have to present scientific theories and objective facts in terms of descriptive phases.

Additionally, in humanities, theoretical concepts and ideas are justified using eventfocused descriptive phases or recounts. In basic sciences, the authors attempted to provide experimental facts through methods, procedures, and processes which necessitate the employment of event-focused phases. This is in accord with Becher and Trowler (2001), who suggested that knowledge in the hard sciences is created via scientific tests and observations. Event-focused phases seem to be related to empirical evidence, representing different ways of establishing knowledge in the disciplines (Chafe \& Nichols, 1986). This is in agreement with the ideas of Kuhn (1970a), who proposed that in normal science, knowledge-making is achieved sequentially so that problems arise from the previous ones.

Table 2 highlights that the descriptive phases comprised an important part of the textbook introductions altogether. Therefore, entity-based description, as well as eventfocused description or recounts, were predominantly employed in humanities and basic sciences textbooks. It is now evident that descriptive genres such as recounts, reports, and explanation play an essential part in establishing more demanding "arguing" genres such as exposition and discussion (Humphrey and Economou, 2015). These findings were in accord with those of Hood (2010) who indicated that recounts and descriptions are frequently encountered in research articles across disciplines, and with the ideas of Martin and Rose (2008) who held that description and recount need to be considered in order to achieve the more complicated academic genres, such as argumentative/persuasive or expository genres. As a result, in identifying academic genres based within SFL, linguists have considered descriptive writing as well as event-based writing, as important genres (Coffin, 2006; Humphrey, 1996).

As shown in Table 2, the analysis was the second prominent feature of the textbook introductions in both disciplines. The analysis was found in distinctive analytic phases, as well as in descriptive, persuasive, and critical phases. It seems that analysis played a key role in establishing a relationship among different phases of the text, in addition to organizing the structure of it in terms of categories and classifications. Moreover, the articles in humanities were more analytic than in basic sciences.

The results might be explained by the fact that the discipline of humanities encourages interpretations and critical involvement on the part of the readers, thus, relating different theoretical notions to each other. Therefore, analysis is required more in humanities to fulfill the function of supporting the author's critical ideas and affective 
evaluations via identifying analytic relationships, categories, and classifications in different phases of the texts. Thus, the critical and reflective nature of humanities, as opposed to the objective and empirical nature of basic sciences may result in the employment of more analytic phases in humanities. The findings are in accord with the ideas of Hyland (2006) who argued that the ways in which knowledge and arguments are established across disciplines vary considerably. That is, soft disciplines such as humanities require are more analytic in order to engage readers in the texts.

The next important feature of the textbook introductions in both disciplines was persuasion, which points to the role of argumentative writing in humanities and basic sciences, and the value of studying textbook introductions as models for student writing. The results of the analysis indicated that basic sciences were more persuasive. The results are likely to be related to the fact that in science the writers are required to provide clear and sound justifications for their claims regarding the scientific facts, experiments, and reports. The results are consistent with the ideas of Hyland (2008) who held that scientific papers seem to be persuasive as they present facts that originated from the natural world. Therefore, it appears essential that students gain familiarity with the persuasive conventions of their disciplines, particularly in basic sciences, in order to persuade the readers of their claims.

Hence, textbook introductions in all disciplines conformed to the onion model of analysis concerning persuasion. To put it simply, persuasive phases were an important feature of the introductions. It appears that the writers employed persuasive writing in order to familiarize the readers with the aim and content of the book and their next claims. These persuasive phases could help writers make readers interested in continuing reading the book since the introductions are typically the first part that the students are faced with. These results were in agreement with the ideas of Asghar, Asghar, \& Mahmood (2015) who contended that the introductions in textbooks aim to establish the field of the work, introduce the book and show gratitude. Furthermore, the findings were in line with those of Bhatia (1997) who maintained that prefaces serve the communicative purpose of introducing the work to the readers.

Moreover, Table 2 indicates that critique comprised the least phases of the texts in both disciplines. Nevertheless, Abbott (2001) argued that critique helps academic authors take a stance within and across disciplines. Critical writing could strengthen the relationship between readers and writers (Hyland, 2008). Thus, the students are required to recognize the discipline-specific conventions of critical writing in order to be accepted as disciplinary members of their communities and to develop effective critical essays. Yet, students may not be able to think and write critically, as the disciplinary conventions of critical writing are not taught explicitly in universities (Jones, 2007). More critical phases were identified in the discipline of humanities. It seems possible that the results are due to the interpretive, controversial, and critical nature of humanities. To put it simply, the subjective evaluative nature of humanities gives rise to the involvement of more critical phases to engage the readers in the interpretive phases. In accordance with the present findings, previous studies have indicated that student writing is shaped and affected by the social practices of their disciplines (Hyland, 1997, 1999, 2008; Kuhn, 1970; MacDonald, 1994).

However, the discipline of basic sciences was considered to be less critical. This finding may be explained by the fact that in basic science the author's authority is 
diminished in favor of the text's authority (Hyland, 2005). In other words, writers tend to present objective impersonal views rather than encouraging affective evaluations and critical engagement on the part of the readers. Hence, in basic sciences, the authors attempt to make their claims more reliable by objectifying and generalizing the interpretive processes (Hyland, 2008). This can be in contrast with humanities which focuses on individuality and expression of subjective ideas.

Humanities. Table 3 presents the frequency and percentage of the discourse patterns present in the Humanities textbook introductions.

Table 3

The Frequency of Discourse Patterns in Sub-Disciplines of Humanities Textbook Introductions

\begin{tabular}{lcccc}
\hline Discourse Patterns & Total & $\begin{array}{c}\text { Applied } \\
\text { linguistics }\end{array}$ & Psychology & Sociology \\
\hline Entity-based description & 74 & 21 & 23 & 30 \\
Event-focused & 88 & 26 & 23 & 39 \\
description & 103 & 35 & 36 & 33 \\
Analysis & 58 & 25 & 17 & 16 \\
Persuasion & 54 & 17 & 16 & 21 \\
Critique & 377 & 124 & 115 & 139 \\
Total & & & & \\
\hline
\end{tabular}

As seen in Table 3, almost equal codes were assigned to entity-based descriptive phases in applied linguistics and psychology. In contrast, more codes were assigned to entity-based descriptive phases in sociology. Hence, it seemed that the entity-based descriptive phases were almost evenly distributed in applied linguistics and psychology. Yet, sociology included more entity-based descriptive phases. The results might be explained considering the interdisciplinary nature of sociology. In other words, sociology draws upon a range of disciplines to investigate the social problems of the world (Burawoy, 2013).

Regarding event-focused descriptive phases, nearly equal codes were assigned to the texts in applied linguistics and psychology. Nonetheless, more event-focused descriptive phases were found in sociology. Therefore, there appeared to be no significant difference in terms of the distribution of the event-focused codes in applied linguistics and psychology. However, more event-focused descriptive phases were found in sociology. This discrepancy could be attributed to the fact that in sociology the authors have to work harder to establish a broad historical, political, and sociological context for the presentation of their claims. These results are in agreement with the ideas of other researchers, who proposed that soft disciplines deal with establishing cognitive and theoretical ways of presenting knowledge since they involve greater contextual unexpected events (Becher \& Trowler, 2001; Hyland, 2005). These results were in line with other disciplinary studies in English (Rothery, 1994) and history (Veel \& Coffin, 1996) which indicated that each of these disciplines employed language in different ways.

Concerning analysis, there seemed to be no significant difference in terms of the distribution of analytic codes in applied linguistics and psychology. Yet, fewer analytic phases appeared in sociology. The reason for this might be that the authors in sociology 
have to provide more theoretical notions than other disciplines to establish the significance of their works and consider alternative points of view (Hyland, 2008; 2015). However, the authors in applied linguistics and psychology tend to employ more analytic phases, as they have to deal with presenting and analyzing various theoretical frameworks of knowledge. Therefore, the authors have to provide a rational background context for these theoretical claims through analytic phases to a greater extent than in sociology.

Table 3 shows that the persuasive codes were almost evenly distributed in psychology and sociology. Nevertheless, more codes were assigned to applied linguistics. One possible explanation may be related to the highly competitive nature of applied linguistics which yields to the presentation of more arguments on the part of the authors in order to persuade the readers of the novelty and importance of their claims (Hyland \& Jiang, 2017). The findings further support the ideas of Coffin et al. (2003), who pointed out that argumentative writing differs not only across disciplines but also within the subdiscipline of humanities.

Concerning critique, the critical codes were almost equally distributed among the sub-disciplines of humanities, although sociology appeared to be slightly more critical. The results might be attributed to the critical nature of humanities, which yield to the involvement of more interpretive phases in the texts. The results match those of Coffin et al. (2003), who stressed that knowledge-making in humanities depends upon how well an argument is presented. In other words, the reader's roles in pondering the problems and interpreting the ideas are taken into account in humanities. In addition, sociology was a bit more critical, given that in sociology authors are required to carefully debate the complexity of important historical, social, and political issues.

\section{Basic sciences.}

Table 4

The Frequency of Codes in Sub-Disciplines of Basic Sciences Textbook Introductions

\begin{tabular}{lllll}
\hline Codes & $\begin{array}{l}\text { All coded } \\
\text { segments }\end{array}$ & Biology & Agriculture & Geology \\
\hline Entity-based description & 84 & 11 & 42 & 31 \\
Event-focused & 74 & 19 & 33 & 21 \\
description & 70 & 20 & 22 & 28 \\
Analysis & 94 & 39 & 30 & 35 \\
Persuasion & 29 & 9 & 11 & 10 \\
Critique & 351 & 98 & 138 & 115 \\
Total & & & & \\
\hline
\end{tabular}

Concerning entity-based descriptive phases, the sub-disciplines of basic sciences fall along a continuum of less descriptive to more descriptive, with biology and geology at each end of the continuum and agriculture in between. The least entity-based descriptive phases were found in biology, while the most entity-based descriptive phases were identified in agriculture. Finally, geology fell in between biology and agriculture. These sub-disciplinary differences in terms of entity-based descriptive phases might indicate that the degree to which the sub-disciplines of basic sciences could assume shared knowledge with readers differed to a great extent. The results coincide with the ideas of Hyland (2015) 
who proposed that authors in humanities could draw upon established theoretical frameworks that are supposed to be shared with the readers.

Furthermore, Table 4 shows that there was almost no difference between biology and geology in terms of the distribution of event-focused descriptive phases. However, more codes were assigned to event-focused phases in agriculture. Thus, knowledge in the hard disciplines is constructed through empirical observation and scientific tests (Becher \& Trowler, 2001).

Additionally, as can be seen from Table 4, geology seemed to be more analytic in comparison to biology and agriculture. The findings might be due to the fact that geology features plenty of statistical techniques in order to analyze and make sense of the experimental data (Shumway, 1987).

For persuasion, biology seemed to be more persuasive than geology and agriculture. Thus, students are demanded to develop more persuasive skills in biology compared to geology and agriculture. To put it simply, they have to become familiar with the acceptable rhetorical structures of their disciplines in order to present their claims and arguments in the most persuasive way (Hyland \& Jiang, 2018).

It can be seen from the data in Table 3, that though, on the whole, the least amount of the codes were assigned to critical phases in the discipline of basic sciences, the critical codes were almost evenly distributed across the sub-disciplines of basic sciences. A possible explanation for these results might be the fact that the theories and experiments are rather neatly presented in basic sciences.

Hence, the authors didn't attempt to involve the readers in the interpretation process and problematize the theoretical notions. Rather, the authors aimed at presenting objectified and impersonal points of view. Thus, the sub-disciplines of basic sciences included fewer critical phases in comparison to humanities. Fewer critical phases in geology and psychology textbooks might be explained by the fact that in the introductory section, the writer attempted to represent the aims of the study and the particular direction toward which the study is going to move, rather than allowing for critical and reflective thinking. The findings corroborate those of Fuller (1993), who maintained that interpreting the results was not a characteristic feature of the students' writings.

\section{Conclusions and implications}

The findings suggested that the textbook introductions conformed greatly to the onion model of analysis. Similarities found between the introductions of textbooks in humanities and basic sciences might suggest that the textbook introductions started with descriptive phases characterized by event-focused and entity-based descriptive segments, which helped establish the context for the study. This descriptive phase moved toward analytic phases which also included descriptive phases. Furthermore, the introductions moved to persuasive phases which included descriptive and analytic segments. In addition, the persuasive phases attempted to provide a justification for the writing of the textbook and the authors' claims. Finally, the critical phases were built upon persuasive phases.

Similarities also occurred with respect to the employment of the appraisal resources and the choice of nominalization, which appeared in entity-based descriptive phases irrespective of disciplines. Therefore, the textbooks were not only informative and descriptive but also persuasive and sometimes critical. The results also highlighted some 
differences between the textbook introductions in the discipline of humanities and those of basic sciences, with reference to the onion model. Differences between the textbook introductions also occurred in terms of the appraisal resources.

Theoretically speaking, this study showed the way in which humanities and basic sciences textbook introductions were organized. It was concluded that persuasive and critical writing is effectively established when analytical and descriptive phases are deployed by the authors in order to provide grounds or reasons for their claims. In addition, effective persuasion and critique are dependent upon the interaction of the appraisal resources, such as the engagement, attitude, and graduation systems, to develop and support the authors' claims or counterclaims.

Additionally, particular attention should be paid to the development of more basic genres such as description and analysis as prerequisites to more complex genres such as persuasion and critique. The close interaction of the appraisal resources typically used to establish these genres should be taken into consideration. Furthermore, teachers should strive to lessen their students' difficulties in academic writing by conducting well-designed training. That is, the expected rhetorical structures of the persuasive and critical phases in the introductions of textbooks should be taught to the students to prepare them to engage in academic writing.

As teachers play a crucial role in scaffolding students' writings through explicit teaching of disciplines' expected rhetorical conventions, in addition to the particular lexicogrammatical choices that interact to create texts, they need a clearer picture of the areas which are worth investigation. Thus, teachers are required to make students aware of the rhetorical conventions and lexico-grammatical choices to provide a framework for the texts to be easily understood. What follows is that more content-based courses are required to help students deconstruct different academic texts and become familiar with the disciplinespecific conventions before embarking on the process of writing (Liu \& Jiang, 2009).

Thus, this study highlights the value of teaching that is concerned with rhetorical consciousness-raising of their disciplines, as well as the discipline-specific lexicogrammatical features in expert texts. This can be achieved when the teachers provide the students with impressions of disciplinary conventions (Johns, 1997). Nevertheless, consciousness-raising could be performed when courses involve texts, particularly expert texts so that students can analyze them and identify specific features of the genres. This process helps students understand how discipline-specific elements are employed, why they are employed, and how these employments vary from one discipline to another.

Additionally, through this process, teachers could draw students' attention, especially advanced level students pursuing masters and doctoral degrees, to features of writing in their disciplines, which in turn, help them identify both the choices available to them and the choice's impact on academic writing.

The findings of the present study may also be useful for material developers. Material development will, to no small extent, be influenced by investigating the discourses that students are required to learn to produce. That is, material developers should select texts which are firmly related to the learners' needs. Thus, they link students' needs to the real world. Additionally, a corpus comprised of various discipline-specific texts might be used to develop materials that accommodate the needs of the students from different faculties. Finally, teachers can use this model to analyze textbook introductions in order to teach their students how to read their textbooks. 
Correspondence should be addressed to Sara Shahab.

Email: Sara.shahab1988@gmail.com

\section{Acknowledgments}

The full affiliations for the authors of this article are as follows:

Sara Shahab, Department of English, Shiraz Branch, Islamic Azad University, Shiraz, Iran. Nasser Rashidi, Department of Foreign Languages and Linguistics, Shiraz University, Shiraz, Iran.

Firooz Sadighi, Department of English, Shiraz Branch, Islamic Azad University, Shiraz, Iran.

Mortaza Yamini, English Department, Zand Institute of Higher Education, Shiraz, Iran.

\section{References}

Abbott, A. (2001). The chaos of disciplines, Chicago: University of Chicago Press.

Abdollahzadeh, E. \& Salarvand, H. (2013). Book prefaces in basic, applied and social sciences: A genre-based study. World Applied Sciences Journal, 28(11), 16181626.

Asghar, S. A., Asghar, Z. M., \& Mahmood, M. A. (2015). A genre analysis of preface sections of textbook. Journal of Education and Practice, 6(7).

Atai, M.R. \& Asghari, M.R. (2017). Exploring disciplinary variation in the generic structure and metadiscourse features of online academic book blurbs. Ampersand.

Atai, M. R., \& Habibi, P. (2012). Genre analysis of applied linguistics research article introductions: Exploring sub-disciplinary variations. Taiwan International ESP Journal, 4(1), 25-44.

Banks, D. (2008).The development of scientific writing: Linguistic features and historical context. London, Oakville: Equinox.

Bacha, N. (2010). Teaching the academic argument in a university EFL environment. Journal of English for Academic Purposes, 9(3), 229-241.

Bartels, N. (Ed.). (2005). Applied Linguistics and Language Teacher Education. New York: Springer.

Bazerman, C. (1988). Shaping written knowledge: The genre and activity of the experimental article in science (Vol. 356). Madison, WI: University of Wisconsin Press.

Becher, T., \& Trowler, P. (2001). Academic tribes and territories: Intellectual enquiry and the culture of disciplines. Buckingham: Society for Research into Higher Education \&Open University Press.

Belk, C. M., \& Borden, V. (2004). Biology: science for life. Pearson Prentice Hall.

Berger, P.L. and Luckmann, T. (1966). The Social Construction of Reality: A Treatise in the Sociology of Knowledge. New York: Doubleday \& Company.

Bhatia, V.K. (1993). Analyzing genre: Language use in professional settings. London: Longman. 
Bhatia, V. K. (1997). Introduction: Genre analysis and world Englishes. World Englishes, 16(3), 313-319.

Biber, D., \& Finegan, E. (1989). Styles of stance in English: Lexical and grammatical marking of evidentiality and affect. Text, 9(1), 93-124.

Bondi, M., \& Hyland, K. (2006). Academic discourse across disciplines (Vol. 42). Bern: Peter Lang.

Böhmer, D., \& Repiská, V., \& Danišovic, L. (2010). Introduction to Medical and Molecular Biology. Asklepios: Bratislava.

Bruner, J. (1960). The process of education. Cambridge, MA: Harvard University Press.

Burawoy, M. (2013). Sociology and interdisciplinarity: The promise and the perils. Philippine Sociological Review, 61(1), 7-19.

Buss, D. M. (Ed.). (2005). The handbook of evolutionary psychology. Hoboken, NJ, US: John Wiley \& Sons Inc.

Chafe, W. \& Nichols, J. (1986). Evidentiality: The linguistic coding of epistemology. Norwood, NJ: Ablex Publishing.

Chanock, K. (2000). Comments on essays: Do students understand what tutors write? Teaching in Higher Education, 5(1), 95-105.

Christie, F. (1987). Young children's writing: From spoken to written genres. Language and Education, 1(1), 3-13.

Coffin, C. (2006). Learning the language of school history: The role of linguistics in mapping the writing demands of the secondary school curriculum. Journal of Curriculum Studies, 38(4), 413-429.

Coffin, C. (2007). Constructing and giving value to the past: An investigation into secondary school history, in F. Christie and J.R. Martin (eds) Knowledge structure: Functional linguistic and sociological perspectives. London: Continuum, 196-230.

Coffin, C., Curry, M.J., Goodman, S., Hewings, A., Lillis, T., \& Swann, J. (2003). Teaching academic writing: A toolkit for higher education. London and New York: Routledge.

Davies, W. M. (2008). 'Not quite right': Helping students to make better arguments. Teaching in Higher Education, 13(3), 327-340.

Debertin, D. L. (1985). Agricultural Production Economics. New York: Macmillan Publishing Company.

Drasovean, A., \& Tagg, C. (2015). Evaluative language and its solidarity-building role on TED.com: An appraisal and corpus analysis.Language@Internet, 12, article 1.

Fryer, D. L. (2007). Multidimensional genre-based discourse analysis of a corpus of English-language medical research articles. Unpublished Master's thesis, University of Oslo.

Gallardo, S. (2005). Pragmatic support of medical recommendations in popularized texts. Journal of Pragmatics, 37(6), 813-835.

Galve, I. G. (1998). The textual interplay of grammatical metaphor on the nominalizations occurring in written medical English. Journal of Pragmatics, 30(3), 363-385.

Griffiths, H., Keirns, N., Strayer, E., Sadler, T., Cody-Rydzewski, S, Scaramuzzo, G, Vyain, S., Bry, J. \& Jones, F. (2017). Introduction to Sociology 2e. Retrieved from https://openstax.org/details/books/introduction-sociology-2e

Gunnarsson, B. L. (2017). Languages of science in the eighteenth century. Berlin: De Gruyter Mouton. 
Halliday, M. A. K. (2004). The grammatical construction of scientific knowledge: The framing of the English clause. In J. J.Webster (Ed.), The language of science, volume 5 of the collected works of M. A. K. Halliday (pp.102-134). London: Continuum.

Halliday, M. A. K. (2008). Complementarities in language. Beijing: The Commercial Press.

Hammond, J. R. (2010). Sociology of the family. $2^{\text {nd }}$ Ed; Free Open Course Ware, Free online text and test banks (www.freesociologybooks.com)

Holmes, R. (1997). Genre analysis, and the social sciences: An investigation of the structure of research article discussion sections in three disciplines. English for Specific Purposes, 16(4), 321-337.

Hilgard, E. R., Atkinson, R. C., \& Atkinson, R. L. (2009). Introduction to psychology. Oxford and IBH Publishing.

Hood, S. (2010). Appraising research: Evaluation in academic writing. London: Palgrave.

Hood, S., \& Forey, G. (2005). Introducing a conference paper: Getting interpersonal with your audience. Journal of English for Academic Purposes, 4(4), 291-306.

Humphrey, S. (1996). Exploring literacy in school geography. Erskineville: NSW/ Metropolitan East Disadvantaged Schools.

Humphrey, S. (2013). And the word became text: A 4 x 4 toolkit for scaffolding writing in secondary English. English in Australia, 48(1), 46.

Humphrey, S. L., \& Economou, D. (2015). Peeling the onion-A textual model of critical analysis. Journal of English for Academic Purposes, 17, 37-50.

Hunston, S. (1989). Evaluation in experimental research articles. Unpublished Ph.D. thesis, University of Birmingham.

Hunston, S., \& Thompson, G. (2000). Evaluation in text: Authorial stance and the construction of discourse: Authorial stance and the construction of discourse. Oxford: Oxford University Press, UK.

Hyland, K. (1998). Persuasion and context: The pragmatics of academic metadiscourse. Journal of Pragmatics, 30(4), 437-455.

Hyland, K. (1999). Academic attribution: Citation and the construction of disciplinary knowledge. Applied Linguistics, 20(3), 341-367.

Hyland, K. (2000). Disciplinary discourses: Social interactions in academic writing. London: Longman.

Hyland, K. (2002). Authority and invisibility: Authorial identity in academic writing. Journal of Pragmatics, 34(8), 1091-1112.

Hyland, K. (2005). Stance and engagement: A model of interaction in academic discourse. Discourse Studies, 7(2), 173-191

Hyland, K. (2006). English for academic purposes: An advanced resource book. London: Routledge.

Hyland, K. (2008). Genre and academic writing in the disciplines. Language Teaching, 41(4), 543-562.

Hyland, K. (2015). Academic publishing: Issues and challenges in the production of knowledge. Oxford: Oxford University Press.

Hyland, K. \& Jiang, K. F., (2015). 'The fact that': Stance nouns in disciplinary writing. Discourse Studies, 17(5), 529-550. 
Hyland, K. \& Jiang, F. K., (2017). Metadiscursive nouns: Interaction and cohesion in abstract moves. English for Specific Purposes, 46, 1-14.

Hyland, K. \& Jiang, K. (2018). "We believe that...” changes in an academic stance marker. Australian Journal of Linguistics, 38(2). 139-161.

Iedema, R., White, P., \& Feez, S. (1994). Media literacy (Write it right literacy in industry research project, stage 2). Sydney: Disadvantaged Schools Program, New South Wales Department of School Education, Metropolitan Eastern region.

Jalilifar, A., Alipour, M., \& Parsa, S. (2014). Comparative study of nominalization in applied linguistics and biology books. Research in Applied Linguistics, 5(1), 24-43.

Jalilifar, A., \& Golkar Musavi, Z. (2016). Genre analysis and genre-mixing across various realizations of academic book introductions in applied linguistics. Journal of Teaching Language Skills, 35(1), 111-138.

Jiang, K. F. (2017). Stance and voice in academic writing: The "noun + that" construction and disciplinary variation. International Journal of Corpus Linguistics, 22(1), 85106.

Jogthong, C. (2001). Research article introductions in Thai: Genre analysis of academic writing. Unpublished Ph.D. dissertation. West Virginia University.

Johns, A. (1997). Text, role, and context. CUP, Cambridge.

Jones, A. (2007). Multiplicities or manna from heaven? Critical thinking and the disciplinary context. Australian Journal of Education, 51(1), 84-103.

King, C. (2010). The planet we live on: The Beginnings of the Earth Sciences. Bloomington, Illinois: Learning Development Institute.

Kuhn, T. S. (1970a). The structure of scientific revolutions, 2nd edition. Chicago, IL, University of Chicago Press.

Lähdesmäki, S. (2009). Intertextual analysis of Finnish EFL textbooks: Genre embedding as recontextualization. In C. Bazerman, A. Bonini, \& D. Figueiredo (Eds.), Genre in a changing world (pp. 375-399). Colorado: Parlor Press.

Lea, M. R., \& Street, B. V. (1998). Student writing in higher education: An academic literacies approach. Studies in Higher Education, 23(2), 157-172.

Lemke, J. L. (1990). Talking science: Language, learning, and values. Norwood,

NJ: Ablex Publishing Corporation.

Liu, D., \& Jiang, P. (2009). Using a corpus-based lexicogrammatical approach to grammar instruction in EFL and ESL contexts. Modern Language Journal, 93(1), 61-78.

Love, A. (1993). Lexico-grammatical features of geology textbooks: Process and product revisited. English for Specific Purposes, 12(3), 197-218.

Love, A. M. (2002). Introductory concepts and 'cutting edge' theories: Can the genre of the textbook accommodate both? In J. Flowerdew (ed.), Academic Discourse, (pp, 7692). New York, NY: Longman.

MacDonald, S. P. (1994). Professional academic writing in the humanities and social sciences.

Carbondale and Edwardsville: Southern Illinois University Press.

Martin, J. R. (1985). Process and text: Two aspects of human semiosis. In J. D. Benson, and W. S. Greaves (Eds.), Systemic perspectives on discourse (pp. 275-294). Norwood, NJ: Ablex.

Martin, J. R. (1992). English text: System and structure. Amsterdam: J. Benjamins. 
Martin, J. R. (1998) 'Mentoring semogenesis: 'Genre-based' literacy pedagogy'. In F. Christie, (Ed.) Pedagogy and the shaping of consciousness: Linguistic and social processes (pp. 123-155). London: Cassell.

Martin, J.R. and Rose, D. (2003) Working with discourse: Meaning beyond the clause. London: Continuum.

Martin, J. R., \& Rose, D. (2008). Genre relations: Mapping culture. London: Equinox.

Martin, J. R., Christie, F., \& Rothery, J. (1987). Social processes in education: A reply to Sawyer and Watson (and others). In I. Reid (Ed.), The place of genre in learning: Current debates (pp. 35-45). Geelong, Australia: Deakin University Press.

Martin, J. R., \& White, P. R. R. (2005). The evaluation of language. New York: Palgrave Macmillan.

Mauranen, A. (2003). "But here's a flawed argument": Socialisation into and through Metadiscourse. Language and Computers, 46(1), 19-34.

Mei, W. S., \& Allison, D. (2009). Evaluative expressions in analytical arguments: Aspects of appraisal in assigned English language essays. Journal of Applied Linguistics, 2(1), 105-127.

Melles, G., \& Lockheart, J. (2012). Writing purposefully in art and design: Responding to converging and diverging new academic literacies. Arts and Humanities in Higher Education, 11(4), 346-362.

Muttaqui, I. A., Banu, N., Hasan, M. A. \& Ahmed, G. A. (2009). Seconday Biology. Dhaka: National Research and Curriculum Board.

Ozturk, I. (2007). The textual organization of research article introductions in applied linguistics: Variability within a single discipline. English for Specific Purposes, 26(1), 25-38.

Parkinson, J. \& Adendorff, R. (2004). The use of popular science articles in teaching scientific literacy. English for Specific Purposes, 23(4), 379-396.

Parodi, G. (2014). Genre organization in specialized discourse: Disciplinary variation across university textbooks. Discourse Studies, 16(1), 65-87.

Pascual, M., \& Unger, L. (2010). Appraisal in the research genres: An analysis of grant proposals by Argentinean researchers. Revista Signos, 43(73).

Pittenger, D. R. (2002). California Master Gardener Handbook. Oakland, CA: the University of California Agriculture and Natural Resources.

Radford, A., Atkinson, M., Britain, D., \& Clahsen, H. (2009). Linguistics an introduction (2nd Ed.). Cambridge: Cambridge University Press.

Reason, P., \& Bradbury, H. (2001). Inquiry and participation in search of a world worthy of human aspiration. In P. Reason \& H. Bradbury (Eds.), Handbook of action research: Participative inquiry and practice (pp. 1-14). London: Sage.

Rose, D. (2007). Towards a reading based theory of teaching. 33rd International Systemic Functional Congress Proceedings 2006. Retrieved from www.pusp.br/isfc/proceedings

Russell, N. (2010). Communicating science. Cambridge: Cambridge University Press.

Samraj, B. (2005). An exploration of a genre set: Research article abstracts and introductions in two disciplines. English for Specific Purposes, 24(2), 141-156.

Samraj, B. (2008). A discourse analysis of Master's theses across disciplines with a focus on introductions. Journal of English for Academic Purposes, 7(1), 55-67. 
Sarosdy, J., Farczadi Bencze, T., Poor Z. \& Vadnay, M. (2006). Applied Linguistics I. Ertekunki az Ember: Bolcsesz Konzorcium.

Schleppegrell, M. J. (2004). The language of schooling: A functional linguistics perspective. London: Routledge.

Shumway, R. H. (1987). Statistics and data analysis in Geology. Technometrics, 29(4), 492.

Swales, J. M. (1981). Aspects of article introductions. Language Studies Unit. Birmingham: University of Aston.

Swales, J. (1990). Genre analysis: English in academic and research settings. Cambridge: Cambridge University Press.

Thompson, G. (2001). Interaction in academic writing: Learning to argue with the reader. Applied Linguistics, 22(1), 58-78.

Unsworth, L. (2001). Teaching multiliteracies across the curriculum. BuckinghamPhiladelphia: Open University Press.

Veel, R. (1997). Learning how to mean scientifically speaking: apprenticeship into scientific discourse in the secondary school. In F. Christie, \& J. R. Martin (Eds.), Genre and institutions: Social processes in the workplace and school (pp. 161195). London: Cassell.

Veel, R., \& Coffin, C (1996). Learning to think like an historian: The language of secondary school history. In: Hasan, Ryqaiya and Williams, Geoff eds. Literacy in society: Applied linguistics and language study (pp. 191-231) London: Longman.

Wang, D., \& An, X. (2013). A study of appraisal in Chinese academic book rReviews. Journal of Language Teaching and Research, 4(6), 1247-1252.

Wardhaugh, R. (2006). An introduction to sociolinguistics. Oxford: Blackwell Publishing Ltd.

Woodward-Kron, R. (2002). Critical analysis versus description? Examining the relationship in successful student writing. Journal of English for Academic Purposes, 1(2), 121-143.

Woodward-Kron, R. (2005). The role of genre and embedded genres in tertiary students' writing. Prospect, 20(3), 24-41.

Wignate, U. (2012). 'Argument!' helping students understand what essay writing is about. Journal of English for Academic Purposes, 11(2), 145-154. 


\section{Appendix}

\section{List of Textbooks Analyzed}

\section{Humanities Textbooks}

\section{Applied Linguistics Textbooks}

Bachman, L. F. (1990). Fundamental Considerations in Language Testing. Oxford: Oxford University Press.

Bartels, N. (Ed.). (2005). Applied Linguistics and Language Teacher Education. New York: Springer.

Chomsky, N. (1957). Syntactic Structures. The Hague: Mouton

Davies, A. (2007). An Introduction to Applied Linguistics. Edinburgh: Edinburgh University Press.

Davies, A., \& Elder, C. (2004). The Handbook of Applied Linguistics. Oxford: Blackwell Publishing Ltd.

Dornyei, Z. (2007). Research Methods in Applied Linguistics: Quantitative, Qualitative, and Mixed Methodologies. Oxford: Oxford University Press.

Hunston, S., \& Oakey, D. (Eds.). (2009). Introducing Applied Linguistics: Concepts and Skills. London: Routledge.

Radford, A., Atkinson, M., Britain, D., \& Clahsen, H. (2009). Linguistics an introduction (2nd Ed.). Cambridge: Cambridge University Press.

Sarosdy, J., Farczadi Bencze, T., Poor Z. \& Vadnay, M. (2006). Applied Linguistics I. Ertekunki az Ember: Bolcsesz Konzorcium.

Schmitt, N. (2010). An introduction to applied linguistics (2nd Ed.). London: Hodder Education.

Wardhaugh, R. (2006). An introduction to sociolinguistics. Oxford: Blackwell Publishing Ltd.

Yule, G. (2016). The study of language. Cambridge: Cambridge University Press.

\section{Psychology Textbooks}

Buss, D. M. (Ed.). (2005). The handbook of evolutionary psychology. Hoboken, NJ, US: John Wiley \& Sons Inc.

Caldini, R. (1984). Influence: The Psychology of Persuasion. New York, NY: William Morrow e Company.

Contino, L. (2013). Introduction to Psychology. Plymouth, MI: Hayden McNeil Publishing.

Coon, D., \& Mitterer, J. O. (2008). Introduction to Psychology: Gateways to Mind and Behavior with Concept Maps and Reviews. (12th ed.). Florence, KY: Cengage.

Feldman, R. S. (2016). Understanding Psychology. New York: McGraw-Hill Education.

Griffiths, H., Keirns, N., Strayer, E., Sadler, T., Cody-Rydzewski, S, Scaramuzzo, G, Vyain, S., Bry, J. \& Jones, F. (2017). Introduction to Sociology 2e. Retrieved from https://openstax.org/details/books/introduction-sociology-2e

Griggs, R. (2014). Psychology: A Concise Introduction. New York, NY: Worth Publishers. Hergenhahn, B.R., \& Henley, T. (2013). An Introduction to the History of Psychology.

Belmont, CA, USA: Wadsworth Cengage Learning. 
Hilgard, E. R., Atkinson, R. C., \& Atkinson, R. L. (2009). Introduction to psychology. Oxford and IBH Publishing.

Ogden, J. (2007). Health Psychology: A Textbook. New York: McGraw-Hill.

Kalat, J. W. (2013). Introduction to Psychology. CA: Wadsworth Publishing.

Stangor, C. (2011). Introduction to Psychology. Canada: Flatworld Knowledge.

\section{Sociology Textbooks}

Berger, P.L. and Luckmann, T. (1966). The Social Construction of Reality: A Treatise in the Sociology of Knowledge. New York: Doubleday \& Company.

Cragun, R.T., Cragun, D. \& Konieczny, P. (2012). Introduction to sociology. https:// upload.wikimedia.org/wikipedia/commons/a/a8/Introduction_to_Sociologyv3.0.pdf.

Date of access: 25 Feb. 2016.

Durkhiem, E. (1985). The Rules of Sociological Method. New York: The Free Press.

Germov, J. (1998). Second Opinion: An Introduction to Health Sociology. South Melbourne, Vic.: Oxford University.

Giddens, A. (1982). Sociology: A Brief but Critical Introduction. Basingstoke \& London, United Kingdom: Macmillan Press.

Giddens, A. (2009). Sociology (revised and updated with Philip W. Sutton). Polity, Cambridge.

Hammond, J. R. (2010). Sociology of the family. $2^{\text {nd }}$ Ed; Free Open Course Ware, Free online text and test banks (www.freesociologybooks.com)

Henslin, J. M. (2010). Sociology: A Down-to-Earth Approach, Boston, MA: Allyn \& Bacon.

Mills, C. W. (1959). The Sociological Imagination. New York: Oxford University Press

Weber, M. (1968). Economy and Society: An Outline of Interpretative Sociology. New York: Bedminster Press.

\section{Basic Sciences Textbooks}

\section{Biology Textbooks}

Belk, C. M., \& Borden, V. (2004). Biology: science for life. Pearson Prentice Hall.

Böhmer, D., \& Repiská, V., \& Danišovic, L. (2010). Introduction to Medical and Molecular Biology. Asklepios: Bratislava.

Darnell, J., \& Lodish, H., \& Baltimore, D. (1986). Molecular Cell Biology. New York: W. H. Freeman and Company.

Doerder, P., \& Gibson, R. (2015).General Biology. Independent.

Holsinger, K. E. (2001-2010). Lecture Notes in Population Genetics. USA: University of Connecticut, Storrs, CT.

Muttaqui, I. A., Banu, N., Hasan, M. A. \& Ahmed, G. A. (2009). Seconday Biology.

Dhaka: National Research and Curriculum Board.

O’Connor, C., \& Adams, J.U. (2010). Essentials of Cell Biology. Cambridge, MA: NPG

Education.

Rittner, D., \& McCabe, T. L. (2004). Encyclopedia of Biology. New York: Facts On File. 
Sterling, K. (1997). Biographical dictionary of American and Canadian naturalists and environmentalists. Westport, Conn.: Greenwood Press.

Thomas, L. (1974). The Lives of a Cell: Notes of a Biology Watcher. New York: Viking Press.

Yount, L. (2003). A to Z of biologists. New York: Facts on File.

\section{Geology Textbooks}

Erickson, J., Coates, D. R., \& Erickson, H. P. (2014). An introduction to fossils and minerals: seeking clues to the earth's past. Infobase Publishing.

Fossen, H. (2016). Structural Geology. Cambridge University Press.Rom, W. N. (2011). Environmental Policy and Public Health: Air Pollution, Global Climate Change, and Wilderness. San Francisco, CA: Jossey-Bass.

Johnson, C., \& Affolter, M., \& Inkenbrandt, P., \& Mosher, C. (2017). An Introduction to Geology. Salt Lake Community College.

King, C. (2010). The planet we live on: The Beginnings of the Earth Sciences.

Bloomington, Illinois: Learning Development Institute.

Marshak, S. (2003). Essentials of Geology. W. W. USA: Norton \& Company.

Morton, M. C. (2017). Aerial Geology: A High-Altitude Tour of North America's Spectacular Volcanoes, Canyons, Glaciers, Lakes, Craters, and Peaks. USA: Timber Press.

Plummer, C., \& Carlson, D., \& Hammersley, L (2012). Physical Geology. New York: McGraw-Hill Education.

Smith, G., \& Pun, A. (2009). How Does Earth Work? Physical Geology and the Process of Science. US: Pearson Education.

Tarbuck, E. J., Lutgens, F. K., Tasa, D. G. (2010). Earth: An Introduction to Physical Geology. US: Pearson Education.

Thurman, H. V. (1983). Essentials of Oceanography. US: Pearson Education.

\section{Agriculture Textbooks}

Brassley, P. (2016). Agriculture: A Very Short Introduction. New York, USA: Oxford University Press.

Burkett, C. W. (2010). Agriculture for Beginners - Revised Edition. Minneapolis: FiliQuarian Classics.

Debertin, D. L. (1985). Agricultural Production Economics. New York: Macmillan Publishing Company.

Fischer, T., \& Byerlee, D., \& Edmeades G. (2014). Crop Yields and Global Food Security: will yield increase continue to feed the world? ACIAR.

Fukuoka, M. (2001). The One-Straw Revolution. Goa, India: Other India Press.

Fuhrer, J., \& Gregory, P. (2014). Climate Change Impact and Adaptation in Agricultural Systems. Wallingford: CAB International.

Grigg, D. (2003). An introduction to agricultural geography. Routledge.

Hamaker, J. D. (2002). The Survival of Civilization. Michigan California: HamakerWeaver Publishers. 
Pittenger, D. R. (2002). California Master Gardener Handbook. Oakland, CA: the University of California Agriculture and Natural Resources.

Steiner, R. (2004). Agriculture Course: The Birth of the Biodynamic Method. East Sussex, United Kingdom: Rudolf Steiner Press. 